\title{
$2{ }^{\circ} \mathrm{C}$ vs. High Warming: Transitions to Flood-Generating Mechanisms across Canada
}

\author{
Bernardo Teufel *(D) and Laxmi Sushama \\ Trottier Institute for Sustainability in Engineering and Design, McGill University, \\ Montréal, QC H3A 0C3, Canada; laxmi.sushama@mcgill.ca \\ * Correspondence: bernardo.teufel@mail.mcgill.ca
}

check for

updates

Citation: Teufel, B.; Sushama, L. $2{ }^{\circ} \mathrm{C}$ vs. High Warming: Transitions to Flood-Generating Mechanisms across Canada. Water 2021, 13, 1494. https://doi.org/10.3390/w13111494

Academic Editor: Maria Mimikou

Received: 15 March 2021

Accepted: 24 May 2021

Published: 27 May 2021

Publisher's Note: MDPI stays neutral with regard to jurisdictional claims in published maps and institutional affiliations.

Copyright: (c) 2021 by the authors. Licensee MDPI, Basel, Switzerland. This article is an open access article distributed under the terms and conditions of the Creative Commons Attribution (CC BY) license (https:// creativecommons.org/licenses/by/ $4.0 /)$.

\begin{abstract}
Fluvial flooding in Canada is often snowmelt-driven, thus occurs mostly in spring, and has caused billions of dollars in damage in the past decade alone. In a warmer climate, increasing rainfall and changing snowmelt rates could lead to significant shifts in flood-generating mechanisms. Here, projected changes to flood-generating mechanisms in terms of the relative contribution of snowmelt and rainfall are assessed across Canada, based on an ensemble of transient climate change simulations performed using a state-of-the-art regional climate model. Changes to flood-generating mechanisms are assessed for both a late 21st century, high warming (i.e., Representative Concentration Pathway 8.5) scenario, and in a $2{ }^{\circ} \mathrm{C}$ global warming context. Under $2{ }^{\circ} \mathrm{C}$ of global warming, the relative contribution of snowmelt and rainfall to streamflow peaks is projected to remain close to that of the current climate, despite slightly increased rainfall contribution. In contrast, a high warming scenario leads to widespread increases in rainfall contribution and the emergence of hotspots of change in currently snowmelt-dominated regions across Canada. In addition, several regions in southern Canada would be projected to become rainfall dominated. These contrasting projections highlight the importance of climate change mitigation, as remaining below the $2{ }^{\circ} \mathrm{C}$ global warming threshold can avoid large changes over most regions, implying a low likelihood that expensive flood adaptation measures would be necessary.
\end{abstract}

Keywords: climate change; regional climate model; flooding; flood-generating mechanisms; $2{ }^{\circ} \mathrm{C}$ warming

\section{Introduction}

The significance of flooding for society is evident, given that flooding frequently leads to fatalities [1,2] and multi-billion dollar damage [3,4]. Fluvial flooding, which occurs when water overflows or breaches a river's banks and then inundates the surrounding area, is responsible for a majority of the most damaging floods in Canadian history [5,6].

An intensification of the hydrological cycle in a future warmer climate is expected [7], which is likely to impact the frequency and severity of extreme hydrological events, including flooding. In Canada, fluvial flooding occurs mostly in spring due to snowmelt or due to combined rain/snowmelt events, while occasionally (mostly for southern watersheds) it can occur in summer and fall because of rainstorms [8,9]. Increasing rainfall extremes over the northern mid-to-high latitudes have already been observed [10], and further intensification is projected in future climates [11-13]. A warmer climate is expected to impact snowmelt events through multiple pathways: on one side, warmer temperatures favor increased snowmelt rates [14]; however, less shortwave energy is available earlier in the snowmelt season, favoring slower snowmelt [15]. Projected changes to both rainfall and snowmelt highlight the potential for significant shifts in flood-generating mechanisms across Canada.

Previous studies on the projected impact of global warming on flood-generating mechanisms have suggested extensive, landscape-scale transformations. For example, 
large areas of the northwestern United States are projected to experience shifts from mixedrain-and-snow to rain-dominant behaviour, along with increased flood risk by the end of the 21st century [16]. Projections over Norway also show the increasing relevance of rainfall as a flood-generating process, where it is projected to replace snowmelt as the dominant process for several basins [17]. Rain-on-snow (ROS) events can trigger major floods due to the contribution of both rainfall and snowmelt, and projections over the Swiss Alps suggest that the number of ROS events could increase by close to $50 \%$ with temperatures $2-4{ }^{\circ} \mathrm{C}$ warmer than present, before declining when temperatures go beyond $4{ }^{\circ} \mathrm{C}$ of warming [18]. ROS events are an important flood-generating mechanism for most of Canada, and increases in ROS characteristics (frequency, rainfall amount, and runoff) are projected during the November to March period for most regions of Canada by 2041-2070, due to increases in rainfall [14].

Projected changes to streamflow (and flooding) are often assessed using hydrological models driven by climate model outputs for various scenarios. Global and regional climate models (GCMs and RCMs), with their water budget including both the atmospheric and land surface branches, are ideal tools to better understand the linkages and feedbacks between climate and hydrological systems, and to evaluate the impact of climate change on streamflow and its generating mechanisms. RCMs offer higher spatial resolution than GCMs, allowing for finer-scale dynamics to be simulated, and are a more adequate tool for generating the information required for regional impact studies. RCMs have been increasingly used to study projected changes to various components of the hydrological cycle, including streamflow [9,19-25].

While previous studies have assessed projected changes to streamflow, this is the first study to explore projected changes to flood-generating mechanisms in terms of the relative contribution of snowmelt and rainfall across Canada, based on an ensemble of transient climate change simulations performed using a state-of-the-art regional climate model. Changes to flood-generating mechanisms are assessed for both a late 21st century, high-warming scenario (i.e., the Representative Concentration Pathway 8.5-RCP8.5), and a $2{ }^{\circ} \mathrm{C}$ global warming context, highlighting the benefits of climate change mitigation and simultaneously informing adaptation measures.

The paper is organized as follows. Section 2 describes the model and simulations used for this study. Section 3 discusses the results, from the validation of streamflow in the current climate, to the evolution of flood-generating mechanisms in future climates, followed by conclusions in Section 4 .

\section{Methods}

This study is based on the limited area version of the Global Environmental Multiscale (GEM) model, used for numerical weather prediction at Environment and Climate Change Canada [26]. It employs semi-Lagrangian transport and a (quasi) fully implicit timestepping scheme. In its fully elastic nonhydrostatic formulation [27], it uses a vertical coordinate based on hydrostatic pressure [28]. In this study, the GEM physics package includes: deep convection following Kain and Fritsch [29], shallow convection based on a transient version of the Kuo [30] scheme [31], large-scale condensation [32], correlated K solar and terrestrial radiation [33], sub-grid-scale orographic gravity wave drag [34], low-level orographic blocking [35], and turbulent kinetic energy closure in the planetary boundary layer and vertical diffusion [36-38].

The land surface scheme used is CLASS v3.6 [39], which is permafrost-enabled as the soil model is $60 \mathrm{~m}$ deep and has both mineral and organic soils represented, important components of high-latitude soils $[40,41]$. The surface and sub-surface runoff calculated by the surface scheme are used to simulate streamflows interactively in GEM using the modified WATROUTE hydrological routing scheme [21,42]. The routing scheme solves the water balance equation at each grid cell and relates water storage to outflow from the grid cell, using Manning's equation. The flow directions, river lengths, and slopes required by the routing scheme are derived from the HydroSHEDS database [43], available 
at 30-arcsecond spatial resolution, following the upscaling method employed by Huziy et al. [22]. Sub-grid lakes are represented using FLake [44].

An ensemble of five GEM simulations are performed for the 1950-2099 period over a pan-Arctic domain at $0.5^{\circ}(\sim 50 \mathrm{~km})$ grid spacing, covering all areas north of $49^{\circ} \mathrm{N}$ and including the entirety of Canada's landmass (Figure 1), using a 20-min time step. Each of these simulations is driven at the boundaries by the corresponding member of the second-generation Canadian Earth System Model (CanESM2) ensemble, following the high-emissions RCP8.5 scenario. Given efforts to significantly reduce the risks and impacts of climate change by "holding the increase in the global mean temperature (GMT) to well below $2{ }^{\circ} \mathrm{C}$ above pre-industrial levels" (Paris Agreement), the simulations are also assessed by assuming that this $2{ }^{\circ} \mathrm{C}$ warming level is not exceeded [45]. According to the Fifth Assessment Report of the Intergovernmental Panel on Climate Change [7], the 1986-2005 reference period is $0.6^{\circ} \mathrm{C}$ warmer than pre-industrial levels. For CanESM2 RCP8.5, the 30-year time slice with a GMT increase of $2{ }^{\circ} \mathrm{C}$ above pre-industrial levels $\left(1.4^{\circ} \mathrm{C}\right.$ above reference levels) corresponds to the 2017-2046 period.
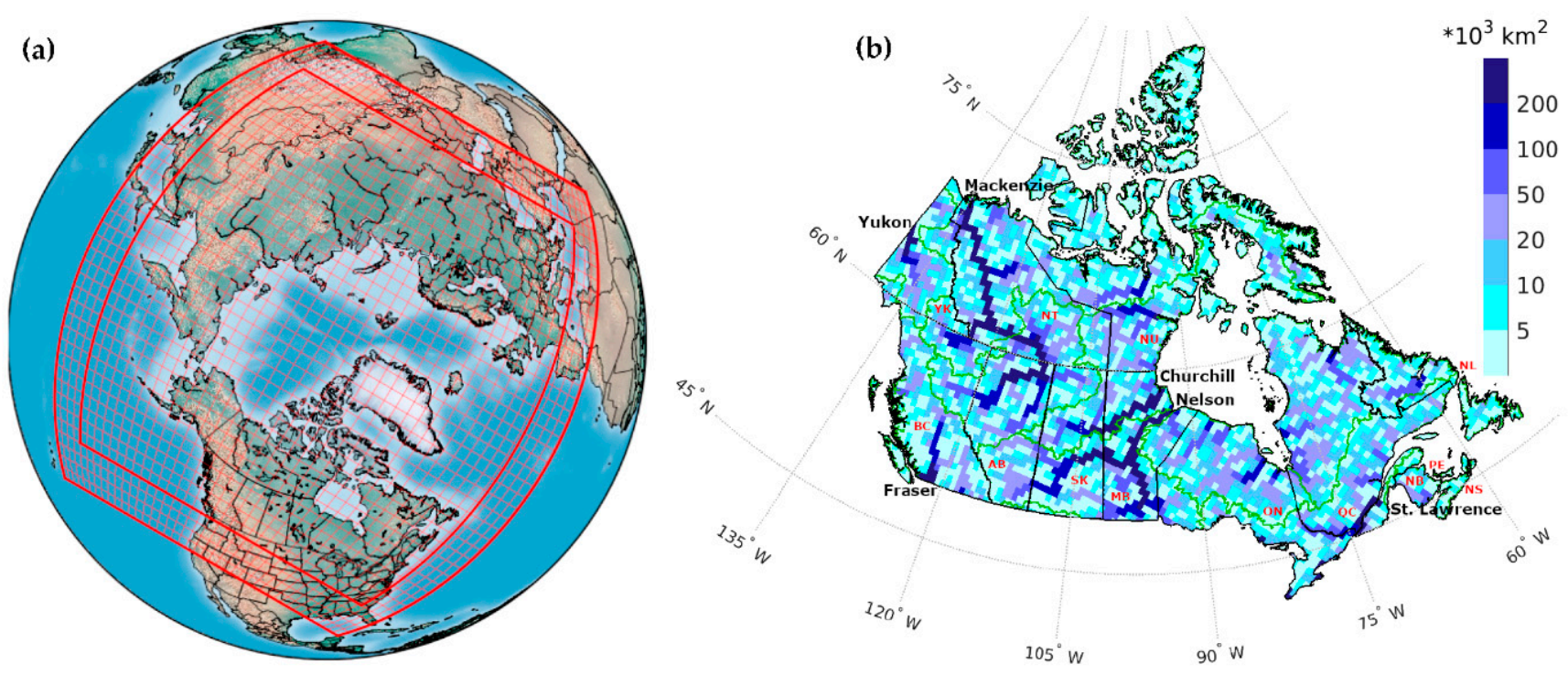

Figure 1. (a) Experimental domain of Global Environmental Multiscale (GEM) simulations, with every fifth grid point shown. The outer thick lines represent the full domain, while the inner thick lines represent the free domain. (b) Upstream drainage area over the analysis domain. Major rivers are named near their outlet. Black lines show the boundaries of Canadian provinces and territories, named with their two letter codes. Green lines show the boundaries of major drainage areas as defined by Water Survey of Canada.

\section{Results and Discussion}

The results are presented in two sections. In the first, floods and their generating mechanisms in GEM are explored in the current climate and validated against observations. In the second, projected changes to flood-generating mechanisms are assessed, for both a $2{ }^{\circ} \mathrm{C}$ warmer globe, and for a high-emissions scenario.

\subsection{Flood-Generating Mechanisms in the Current Climate}

\subsubsection{Streamflow Validation}

As discussed in Section 2, the version of GEM used for this study simulates streamflow at every model time step. To focus on the performance of GEM for events potentially leading to flooding, the peak daily streamflow is selected for each year, and its magnitude and date of occurrence compared to those at hydrometric stations in the Canadian National Water Data Archive HYDAT database. A total of 747 HYDAT stations recording natural streamflow and having at least 30 years of data in the 1971-2020 period are considered for validation. Both the magnitude and date of annual maximum streamflow (AMS) events are 
recorded. The average date of maximum streamflow occurrence is derived using circular statistics (i.e., by mapping the days of the year on the unit circle). This date is assumed to be representative of most events at the station when at least $50 \%$ of events occur within 30 days of the average date. The magnitude of the 1 in 10-year event is approximated by the 90th percentile, and its magnitude normalized by the median event, giving a measure of the variability of streamflow at each station.

Figure 2 shows that GEM captures all the major rivers in Canada, and the timing of peak streamflow appears reasonable, generally occurring earlier for the warmer southern regions and later farther north. In some regions of central Canada (shown in grey), the average timing of peak streamflow is very variable, suggesting that more than one mechanism could lead to flooding in this region. As in observations, GEM suggests that streamflow in the Prairie region is more variable from year to year than for rest of Canada. Direct comparison at HYDAT stations where drainage area is within $20 \%$ of the value used in GEM reveals that GEM underestimates the median AMS by around 30\%, and the AMS occurs on average 6 days later in GEM, for the median station. Compared to similar studies, it can be said that GEM is able to reasonably capture the magnitude, the timing, and the variability of peak streamflow with respect to observations over most regions.
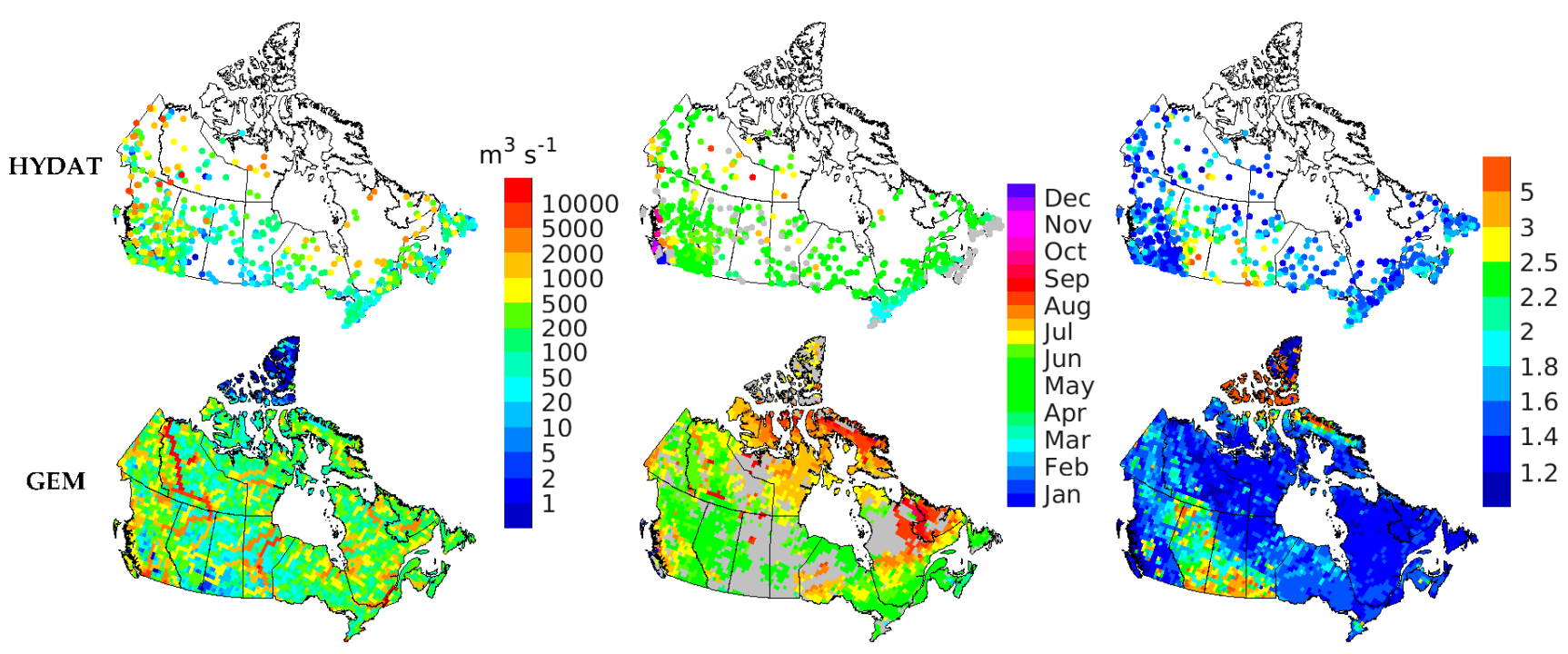

Figure 2. Median annual maximum streamflow (first column), its average date of occurrence (second column), and ratio between 1 in 10-year and median annual maximum streamflow (third column), for the 1971-2020 period, from HYDAT (top row) and GEM (bottom row). Grey is used for the date at locations where less than $50 \%$ of annual maximum events occur within 30 days of the average date. Where multiple HYDAT observations overlap, the one with the highest streamflow is shown on top.

\subsubsection{Flood-Generating Mechanisms}

Given that the two processes contributing virtually all liquid water at the surface are snowmelt and rainfall, any streamflow peak can be traced back to these two components, after considering delays in surface and groundwater transport. These delays also imply that an extended period of snowmelt and/or rainfall is required to generate a notable streamflow peak, at least at the scales considered in this study, which exclude flash flooding.

The analysis of flood-generating mechanisms in the current climate (1981-2010) focuses on the 150 largest streamflow events (30 years times 5 ensemble members) at each grid point. To ensure that these events are independent, a minimum 90-day separation between events is enforced. It is hypothesized that each of these events is caused by snowmelt, rainfall, or both, falling over the upstream contributing basin prior to the event. To take into account some of the hydrological characteristics of each basin, varying moving windows for accumulation of rainfall and snowmelt (from 1 to 90 days), and varying delays between the accumulation window and the date of maximum streamflow (also from 1 to 
90 days) are considered at each grid point. The accumulation window and delay that best explain the variability in streamflow are chosen on the basis of the maximum correlation coefficient between accumulated snowmelt/rainfall and streamflow for the 150 events. To establish the relative contribution of snowmelt and rainfall, it suffices to compare the contribution of each over the accumulation window at each location.

Figure 3 shows that the amount of snowmelt/rainfall falling over the contributing basin is strongly correlated with the magnitude of the corresponding ensuing streamflow event. The value of the correlation coefficient is close to one over some parts of the high Arctic, where permafrost forces hydrological processes to occur very close to the land surface. Lower correlations over central Canada again suggest multiple flood-generating mechanisms over this region, with potentially varying accumulation windows and delays. Figure 3 also shows the relative contribution of snowmelt and rainfall to streamflow events. As expected, both snowmelt and rainfall contribute significantly to flood generation over most of Canada, with warmer regions having slightly more rainfall contribution. Over northern Canada, as well as the western mountain ranges, the snowmelt contribution exceeds (often significantly) the rainfall contribution.
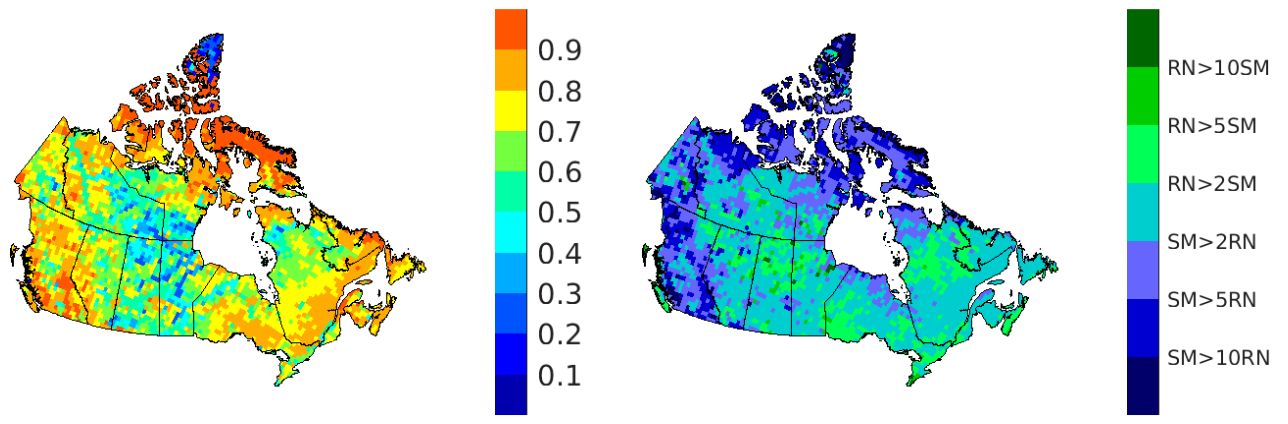

Figure 3. Correlation coefficient between streamflow and accumulated snowmelt/rainfall upstream of respective grid cell in GEM for the 150 largest streamflow events during the 1981-2010 period (left). Relative average snowmelt (SM) and rainfall (RN) contribution during those events (right).

\subsubsection{Intense Floods}

Given that higher streamflows are more likely to lead to flooding, it should be assessed whether the relative contribution of rainfall and snowmelt varies with the magnitude of the streamflow event. To assess whether 1 in 10-year events behave differently, the average relative contribution is calculated using only the 15 largest events (instead of 150). Figure 4 shows that, over many regions, the largest events are characterized by decreased rainfall contribution (i.e., increased snowmelt contribution). Interestingly, this also occurs along the course of several large rivers (e.g., Mackenzie).
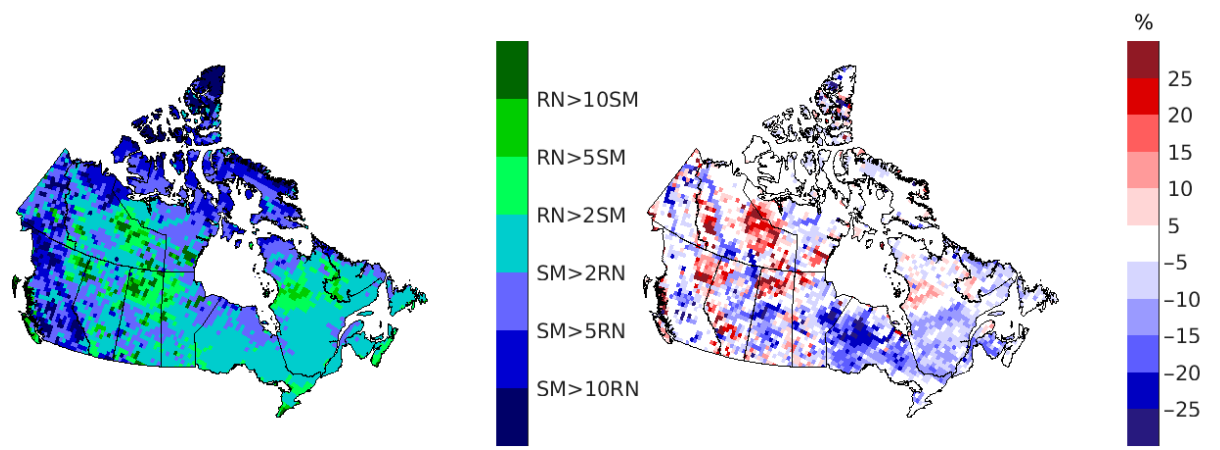

Figure 4. Relative average snowmelt and rainfall contribution in GEM for the 15 largest streamflow events during the 1981-2010 period (left). Difference in rainfall contribution with respect to the average rainfall contribution during the 150 largest streamflow events (right). 


\subsection{Projected Changes to Flood-Generating Mechanisms}

\subsubsection{Projected Changes to Streamflow}

As discussed in Section 1, a warmer climate is expected to impact streamflow events through multiple pathways, including changes to rainfall, snow accumulation, and melt rates, as well as evapotranspiration and infiltration rates. Figure 5 shows that GEM projects both increases and decreases in median annual maximum streamflow over Canada, with the strongest relative increases projected for the high Arctic (where both snowmelt and rainfall are projected to increase significantly), while large regions of central and western Canada are projected to experience decreases in peak streamflow. The date of occurrence of peak streamflow is projected to become earlier in spring over virtually all regions where such a projection can be made (Figure 5), as a consequence of earlier snowmelt. The year-to-year variability in streamflow is not projected to change significantly over most regions (not shown). Under a $2{ }^{\circ} \mathrm{C}$ warming, changes are projected to be relatively small, with most regions projected to stay within $10 \%$ in magnitude and 15 days in timing of peak streamflow. In contrast, following a high-emissions scenario leads to significant changes in streamflow magnitude over large regions, and shifts of up to 2 months in the average date of occurrence of peak streamflow, thereby increasing the likelihood that adaptation measures would be required.
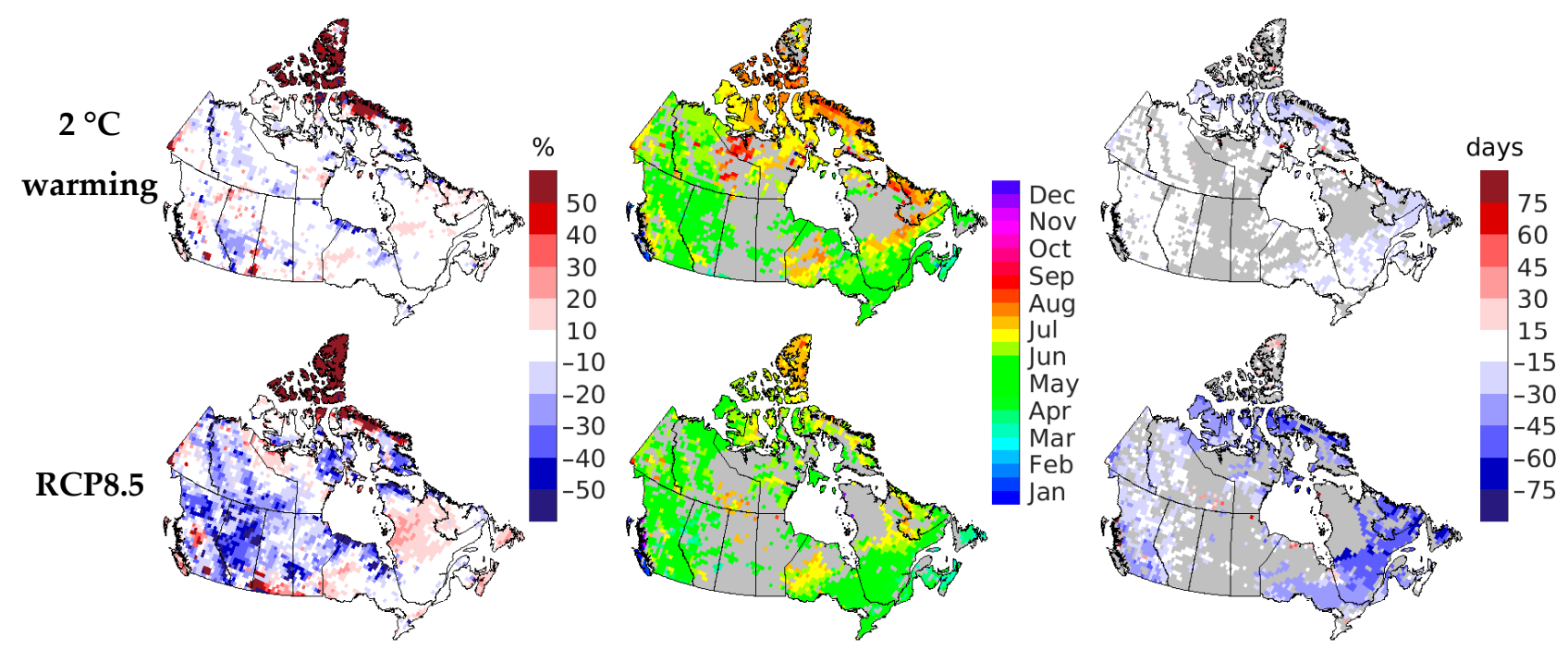

Figure 5. Projected changes to median annual maximum streamflow with respect to 1981-2010 (first column), projected average date of occurrence of annual maximum streamflow (second column), and its projected changes with respect to 1981-2010 (third column). Projections for both $2{ }^{\circ} \mathrm{C}$ warming (top row) and RCP8.5 2070-2099 (bottom row) are shown. Grey is used for the date at locations where less than $50 \%$ of annual maximum events occur within 30 days of the average date.

\subsubsection{Transitions to Flood-Generating Mechanisms}

Figure 6 shows that the amount of snowmelt/rainfall falling over the contributing basin is projected to remain strongly correlated with the magnitude of the corresponding ensuing streamflow event in a warmer climate, with spatial patterns resembling those seen in Figure 3 and discussed in Section 3.1.2. Under $2{ }^{\circ} \mathrm{C}$ of global warming, the relative contribution of snowmelt and rainfall to streamflow peaks is projected to remain close to the 1981-2010 reference period, with some projected increases in rainfall contribution over Ontario and southern Quebec (Figure 6), but both components remain close in magnitude. In contrast, following a high-emissions scenario leads to generally higher rainfall contributions over Canada and the emergence of hotspots of change over central Nunavut, Nunavik, the west coast, and northern Ontario, where rainfall contribution is projected to significantly alter the currently snowmelt-dominated regime, as well as the southern Prairies, where rainfall is projected to become the dominant factor. In addition, warmer 
regions such as Vancouver Island, southern Ontario, and parts of the Maritimes are also projected to become rainfall-dominated.
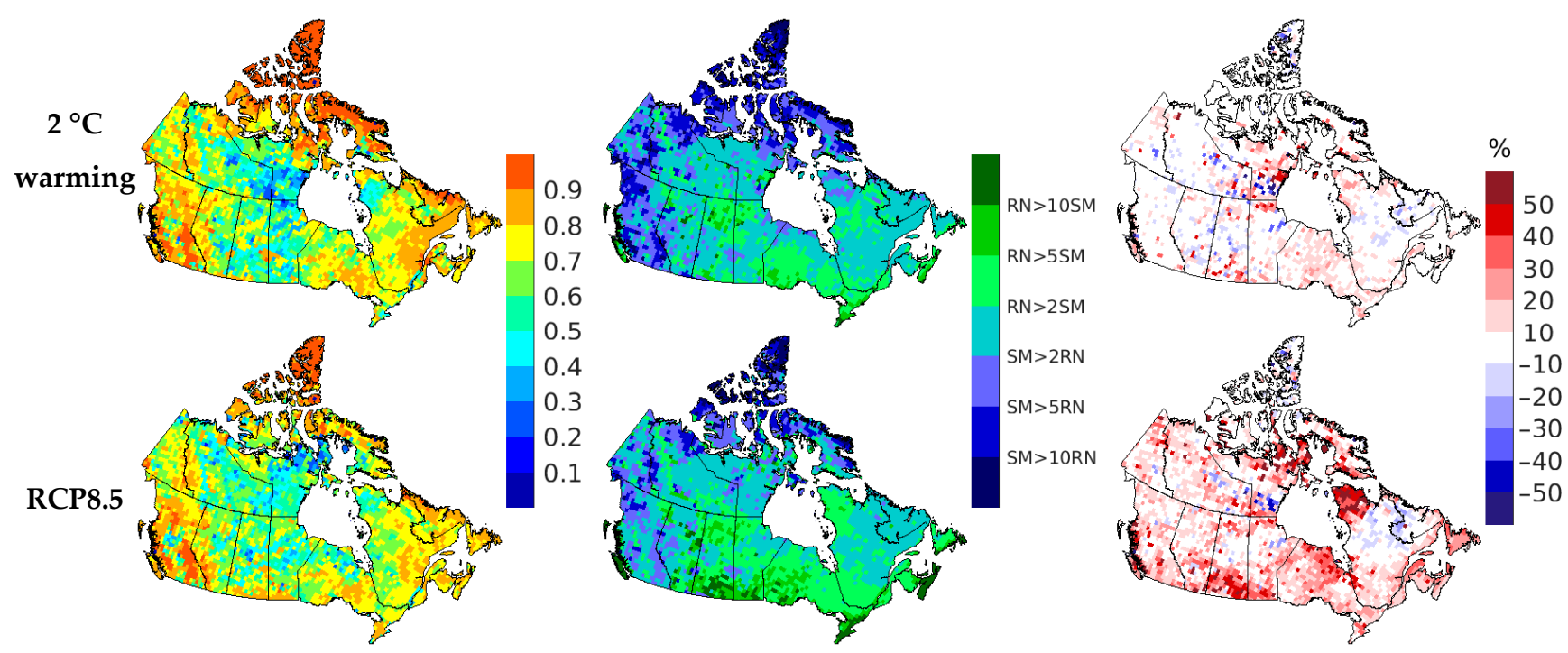

Figure 6. Correlation coefficient between streamflow and accumulated snowmelt/rainfall upstream of respective grid cell in GEM for the 150 largest streamflow events (first column), relative average snowmelt and rainfall contribution during those events (second column), and projected changes to the rainfall contribution during those events with respect to 1981-2010 (third column). Projections for both $2{ }^{\circ} \mathrm{C}$ warming (top row) and RCP8.5 2070-2099 (bottom row) are shown.

\section{Conclusions}

The implications of the projections presented in Section 3 vary depending on the region and the vulnerability of natural and built systems in the region. Increased peak streamflow, as projected for several regions, has the direct implication of increased flood risk. Decreased peak streamflow, while positive from the flooding perspective, hints at potential decreases in total streamflow, which has important implications for freshwater resources. The same can be said for shifts in streamflow distribution throughout the year, linked to shifts in the average date of peak streamflow, which additionally have implications for flow regulation plans in the affected regions.

Like most previous RCM-based studies on flooding, this study uses high streamflow (or discharge) as a proxy for flooding, which constitutes a good approximation under the assumption of a fixed stage-discharge relationship. However, extreme flooding in Canadian rivers is frequently the result of ice jams [46], particularly for north-flowing rivers, with water levels for a given discharge greatly exceeding those occurring under open-water conditions, due to the well-known hydraulic effects of ice on flow conveyance. Given warming temperatures, the probability of mid-winter ice jams is likely to increase across many regions, constituting a major threat to riverside communities and infrastructure $[47,48]$. Simulations of projected changes to river ice and ice jam mechanisms are thus needed and are currently being implemented in models.

While the $\sim 50 \mathrm{~km}$ grid spacing used in this study is sufficient for the identification of potential hotspots of change at regional scales, higher resolution is required for assessing impacts at local scales. This would also allow studying flash flooding in smaller basins, which might increase in a warmer climate, given the significant projected increases in short-duration rainfall [49]. Site-specific impact studies can be performed with the aid of hydrodynamic models, which can explicitly simulate inundation area and flood depths, and are often used to provide flood-risk mapping [50]. The flow boundary conditions required for mapping purposes could be taken from high-resolution RCM simulations of streamflow. 
Author Contributions: Conceptualization, L.S. and B.T.; methodology, L.S. and B.T.; formal analysis, B.T.; investigation, B.T.; resources, L.S.; writing-original draft preparation, B.T.; writing-review and editing, L.S.; visualization, B.T.; supervision, L.S.; funding acquisition, L.S. All authors have read and agreed to the published version of the manuscript.

Funding: This research was funded by the Trottier Institute for Sustainability in Engineering and Design (TISED) and the Natural Sciences and Engineering Research Council of Canada (NSERC).

Institutional Review Board Statement: Not applicable.

Informed Consent Statement: Not applicable.

Data Availability Statement: The data presented in this study are available on request from the corresponding author.

Acknowledgments: The GEM simulations considered in this study were performed on supercomputers managed by Calcul Québec and Compute Canada.

Conflicts of Interest: The authors declare no conflict of interest.

\section{References}

1. Ashley, S.T.; Ashley, W.S. Flood Fatalities in the United States. J. Appl. Meteorol. Climatol. 2008, 47, 805-818. [CrossRef]

2. Mohanty, M.P.; Simonovic, S.P. Understanding dynamics of population flood exposure in Canada with multiple high-resolution population datasets. Sci. Total Environ. 2021, 759, 143559. [CrossRef] [PubMed]

3. Jongman, B.; Ward, P.J.; Aerts, J.C.J.H. Global exposure to river and coastal flooding: Long term trends and changes. Glob. Environ. Chang. 2012, 22, 823-835. [CrossRef]

4. Winsemius, H.C.; Aerts, J.C.; Van Beek, L.P.; Bierkens, M.F.; Bouwman, A.; Jongman, B.; Kwadijk, J.C.; Ligtvoet, W.; Lucas, P.L.; Van Vuuren, D.P.; et al. Global drivers of future river flood risk. Nat. Clim. Chang. 2016, 6, 381-385. [CrossRef]

5. Teufel, B.; Diro, G.T.; Whan, K.; Milrad, S.M.; Jeong, D.I.; Ganji, A.; Huziy, O.; Winger, K.; Gyakum, J.R.; de Elia, R.; et al. Investigation of the 2013 Alberta flood from weather and climate perspectives. Clim. Dynam. 2017, 48, 2881-2899. [CrossRef]

6. Teufel, B.; Sushama, L.; Huziy, O.; Diro, G.T.; Jeong, D.I.; Winger, K.; Garnaud, C.; de Elia, R.; Zwiers, F.W.; Matthews, H.D.; et al. Investigation of the mechanisms leading to the 2017 Montreal flood. Clim. Dynam. 2019, 52, 4193-4206. [CrossRef]

7. IPCC. Climate Change 2013: The Physical Science Basis. Contribution of Working Group I to the Fifth Assessment Report of the Intergovernmental Panel on Climate Change; Stocker, T.F., Qin, D., Plattner, G.-K., Tignor, M., Allen, S.K., Boschung, J., Nauels, A., Xia, Y., Bex, V., Midgley, P.M., Eds.; Cambridge University Press: Cambridge, UK; New York, NY, USA, 2013; p. 1535. [CrossRef]

8. Javelle, P.; Ouarda, T.B.M.J.; Lang, M.; Bobée, B.; Galéa, G.; Grésillon, J.-M. Development of regional flood-duration-frequency curves based on the index-flood method. J. Hydrol. 2002, 258, 249-259. [CrossRef]

9. Clavet-Gaumont, J.; Sushama, L.; Khaliq, M.N.; Huziy, O.; Roy, R. Canadian RCM projected changes to high flows for Québec watersheds using regional frequency analysis. Int. J. Clim. 2013, 33, 2940-2955. [CrossRef]

10. Westra, S.; Alexander, L.; Zwiers, F. Global increasing trends in annual maximum daily precipitation. J. Clim. 2013, 26, 3904-3918. [CrossRef]

11. Mladjic, B.; Sushama, L.; Khaliq, M.N.; Laprise, R.; Caya, D.; Roy, R. Canadian RCM Projected Changes to Extreme Precipitation Characteristics over Canada. J. Clim. 2011, 24, 2565-2584. [CrossRef]

12. Monette, A.; Sushama, L.; Khaliq, M.N.; Laprise, R.; Roy, R. Projected changes to precipitation extremes for northeast Canadian watersheds using a multi-RCM ensemble. J. Geophys. Res. Atmos. 2012, 117. [CrossRef]

13. Khaliq, M.N.; Sushama, L.; Monette, A.; Wheater, H. Seasonal and extreme precipitation characteristics for the watersheds of the Canadian Prairie Provinces as simulated by the NARCCAP multi-RCM ensemble. Clim. Dynam. 2015, 44, 255-277. [CrossRef]

14. Jeong, D.I.; Sushama, L. Rain-on-snow events over North America based on two Canadian regional climate models. Clim. Dynam. 2018, 50, 303-316. [CrossRef]

15. Musselman, K.N.; Clark, M.P.; Liu, C.; Ikeda, K.; Rasmussen, R. Slower snowmelt in a warmer world. Nat. Clim. Chang. 2017, 7, 214. [CrossRef]

16. Hamlet, A.F.; Elsner, M.M.; Mauger, G.S.; Lee, S.-Y.; Tohver, I.; Norheim, R.A. An Overview of the Columbia Basin Climate Change Scenarios Project: Approach, Methods, and Summary of Key Results. Atmos. Ocean 2013, 51, 392-415. [CrossRef]

17. Vormoor, K.; Lawrence, D.; Heistermann, M.; Bronstert, A. Climate change impacts on the seasonality and generation processes of floods-Projections and uncertainties for catchments with mixed snowmelt/rainfall regimes. Hydrol. Earth Syst. Sci. 2015, 19, 913-931. [CrossRef]

18. Beniston, M.; Stoffel, M. Rain-on-snow events, floods and climate change in the Alps: Events may increase with warming up to $4{ }^{\circ} \mathrm{C}$ and decrease thereafter. Sci. Total Environ. 2016, 571, 228-236. [CrossRef]

19. Kay, A.L.; Reynard, N.S.; Jones, R.G. RCM rainfall for UK flood frequency estimation. I. Method and validation. J. Hydrol. 2006, 318, 151-162. [CrossRef] 
20. Sushama, L.; Laprise, R.; Caya, D.; Frigon, A.; Slivitzky, M. Canadian RCM projected climate-change signal and its sensitivity to model errors. Int. J. Clim. 2006, 26, 2141-2159. [CrossRef]

21. Poitras, V.; Sushama, L.; Seglenieks, F.; Khaliq, M.N.; Soulis, E. Projected Changes to Streamflow Characteristics over Western Canada as Simulated by the Canadian RCM. J. Hydrometeorol. 2011, 12, 1395-1413. [CrossRef]

22. Huziy, O.; Sushama, L.; Khaliq, M.N.; Laprise, R.; Lehner, B.; Roy, R. Analysis of streamflow characteristics over Northeastern Canada in a changing climate. Clim. Dynam. 2013, 40, 1879-1901. [CrossRef]

23. Jeong, D.I.; Sushama, L.; Khaliq, M.N.; Roy, R. A copula-based multivariate analysis of Canadian RCM projected changes to flood characteristics for northeastern Canada. Clim. Dynam. 2014, 42, 2045-2066. [CrossRef]

24. Huziy, O.; Sushama, L. Lake-river and lake-atmosphere interactions in a changing climate over Northeast Canada. Clim. Dynam. 2017, 48, 3227-3246. [CrossRef]

25. Huziy, O.; Sushama, L. Impact of lake-river connectivity and interflow on the Canadian RCM simulated regional climate and hydrology for Northeast Canada. Clim. Dynam. 2017, 48, 709-725. [CrossRef]

26. Côté, J.; Gravel, S.; Méthot, A.; Patoine, A.; Roch, M.; Staniforth, A. The Operational CMC-MRB Global Environmental Multiscale (GEM) Model. Part I: Design Considerations and Formulation. Mon. Weather Rev. 1998, 126, 1373-1395. [CrossRef]

27. Yeh, K.-S.; Côté, J.; Gravel, S.; Méthot, A.; Patoine, A.; Roch, M.; Staniforth, A. The CMC-MRB Global Environmental Multiscale (GEM) Model. Part III: Nonhydrostatic Formulation. Mon. Weather Rev. 2002, 130, 339-356. [CrossRef]

28. Laprise, R. The Euler Equations of Motion with Hydrostatic Pressure as an Independent Variable. Mon. Weather Rev. 1992, 120, 197-207. [CrossRef]

29. Kain, J.S.; Fritsch, J.M. A One-Dimensional Entraining Detraining Plume Model and Its Application in Convective Parameterization. J. Atmos. Sci. 1990, 47, 2784-2802. [CrossRef]

30. Kuo, H.L. On Formation and Intensification of Tropical Cyclones through Latent Heat Release by Cumulus Convection. J. Atmos. Sci. 1965, 22, 40-63. [CrossRef]

31. Belair, S.; Mailhot, J.; Girard, C.; Vaillancourt, P. Boundary layer and shallow cumulus clouds in a medium-range forecast of a large-scale weather system. Mon. Weather Rev. 2005, 133, 1938-1960. [CrossRef]

32. Sundqvist, H.; Berge, E.; Kristjansson, J.E. Condensation and Cloud Parameterization Studies with a Mesoscale Numerical Weather Prediction Model. Mon. Weather Rev. 1989, 117, 1641-1657. [CrossRef]

33. Li, J.; Barker, H.W. A radiation algorithm with correlated-k distribution. Part I: Local thermal equilibrium. J. Atmos. Sci. 2005, 62, 286-309. [CrossRef]

34. Mcfarlane, N.A. The Effect of Orographically Excited Gravity-Wave Drag on the General-Circulation of the Lower Stratosphere and Troposphere. J. Atmos. Sci. 1987, 44, 1775-1800. [CrossRef]

35. Zadra, A.; Roch, M.; Laroche, S.; Charron, M. The subgrid-scale orographic blocking parametrization of the GEM model. Atmos. Ocean 2003, 41, 155-170. [CrossRef]

36. Benoit, R.; Cote, J.; Mailhot, J. Inclusion of a Tke Boundary-Layer Parameterization in the Canadian Regional Finite-Element Model. Mon. Weather Rev. 1989, 117, 1726-1750. [CrossRef]

37. Delage, Y.; Girard, C. Stability Functions Correct at the Free-Convection Limit and Consistent for Both the Surface and Ekman Layers. Bound. Layer Meteorol. 1992, 58, 19-31. [CrossRef]

38. Delage, Y. Parameterising sub-grid scale vertical transport in atmospheric models under statically stable conditions. Bound. Layer Meteorol. 1997, 82, 23-48. [CrossRef]

39. Verseghy, D.L. CLASS—The Canadian Land Surface Scheme (Version 3.5), Technical Documentation (Version 1); Climate Research Division, Science and Technology Branch: Vancouver, BC, Canada, 2011.

40. Teufel, B.; Sushama, L.; Arora, V.K.; Verseghy, D. Impact of dynamic vegetation phenology on the simulated pan-Arctic land surface state. Clim. Dynam. 2018, 52, 373-388. [CrossRef]

41. Teufel, B.; Sushama, L. Abrupt changes across the Arctic permafrost region endanger northern development. Nat. Clim. Chang. 2019, 9, 858-862. [CrossRef]

42. Soulis, E.D.; Snelgrove, K.R.; Kouwen, N.; Seglenieks, F.; Verseghy, D.L. Towards closing the vertical water balance in Canadian atmospheric models: Coupling of the land surface scheme class with the distributed hydrological model watflood. Atmos. Ocean 2000, 38, 251-269. [CrossRef]

43. Lehner, B.; Verdin, K.; Jarvis, A. New Global Hydrography Derived From Spaceborne Elevation Data. EosTrans. Am. Geophys. Union 2008, 89, 93-94. [CrossRef]

44. Mironov, D.V. Parameterization of Lakes in Numerical Weather Prediction. Part 1: Description of a Lake Model; German Weather Service: Offenbach am Main, Germany, 2008.

45. Schleussner, C.-F.; Rogelj, J.; Schaeffer, M.; Lissner, T.; Licker, R.; Fischer, E.M.; Knutti, R.; Levermann, A.; Frieler, K.; Hare, W. Science and policy characteristics of the Paris Agreement temperature goal. Nat. Clim. Chang. 2016, 6, 827-835. [CrossRef]

46. de Rham, L.; Dibike, Y.; Beltaos, S.; Peters, D.; Bonsal, B.; Prowse, T. A Canadian River Ice Database from the National Hydrometric Program Archives. Earth Syst. Sci. Data 2020, 12, 1835-1860. [CrossRef]

47. Beltaos, S. Effects of climate on mid-winter ice jams. Hydrol. Process. 2002, 16, 789-804. [CrossRef]

48. Beltaos, S.; Ismail, S.; Burrell, B.C. Midwinter breakup and jamming on the upper Saint John River: A case study. Can. J. Civ. Eng. 2003, 30, 77-88. [CrossRef] 
49. Oh, S.-G.; Sushama, L. Short-duration precipitation extremes over Canada in a warmer climate. Clim. Dynam. 2020, 54, 2493-2509. [CrossRef]

50. Teng, J.; Jakeman, A.J.; Vaze, J.; Croke, B.F.W.; Dutta, D.; Kim, S. Flood inundation modelling: A review of methods, recent advances and uncertainty analysis. Environ. Model. Softw. 2017, 90, 201-216. [CrossRef] 